\title{
PEREMPUAN DAN KEBEBASAN: SEBUAH EKSPLORASI ATAS LEGENDA JAKA TARUB
}

\author{
DOl: https://doi.org/10.33550/sd.v7i1.139
}

\section{Andreas Maurenis Putra}

Yayasan Sahabat Lingkungan Hidup

\begin{abstract}
This article is an exploration to find liberation messages for women based on folklore,"Jaka Tarub dan Tujuh Bidadari." Although it is not a perfect study, it is very important to provide an understanding of the polemic of civilization which is always be a hot topic for discussion. Gender problems are global and local human problems. This issues are continually debates and discusses, especially by women who demands respect for human qualities in a balanced way. The legend of "Jaka Tarub dan Tujuh Bidadari" became the key to dissecting the context of society, past and present, about the massive gender issues (especially due to the strong patriarchal culture) which then ignites various forms of women's movements to reconstruct the principle of balance because basically, humans are the image of God. Using the text analysis method, this article presents a new perspective that women, like men, have the right to express their talents in building a better world.
\end{abstract}

KEYWORDS: folklore, patriarchal, woman, egalitarian, cooperation.

ABSTRAK: Artikel ini merupakan sebuah eksplorasi untuk menemukan pesan-pesan pembebasan bagi kaum perempuan berdasarkan cerita rakyat, "Jaka Tarub dan Tujuh Bidadari." Meskipun bukan merupakan telaah yang sempurna tetapi sangat cukup untuk memberi pemahaman tentang polemik peradaban, yang senantiasa menjadi topik hangat untuk diperbincangkan. 
Masalah gender adalah masalah manusia global dan lokal. Masalah ini terus-menerus diperdebatkan dan diperbincangkan terutama oleh kaum perempuan yang menuntut penghargaan atas kualitas manusia secara seimbang. Legenda "Jaka Tarub dan Tujuh Bidadari” menjadi kunci untuk membedah konteks masyarakat dulu dan sekarang tentang masifnya persoalan gender (terutama karena kuatnya budaya patriarki) yang kemudian menyulut aneka bentuk gerakan perempuan untuk merekonstruksi prinsip keseimbangan, karena pada dasarnya, manusia adalah citra Allah. Menggunakan metode analisis teks, artikel ini menyajikan sebuah cara pandang baru bahwa perempuan, sebagaimana laki-laki, berhak mengekspresikan talenta-talentanya dalam membangun dunia menjadi lebih baik.

KATA-KATA KUNCI: legenda, patriarki, perempuan, egaliter, kerja sama.

\section{Pendahuluan}

Perbedaan gender selalu menjadi polemik, baik di masa lalu maupun masa kini. ${ }^{1}$ Di dalam masyarakat yang mengenal sistem patriarki, status perempuan dianggap lebih rendah ketimbang laki-laki. Raden Ajeng Kartini, tokoh gerakan perempuan Indonesia, pun mengalami hal yang serupa di masanya. Kartini dipaksa pulang dari studinya di Belanda untuk dinikahkan dengan bupati Rembang. Identitasnya sebagai seorang perempuan seakan-akan ditertibkan. Menjadi seorang perempuan (Jawa) berarti harus selalu siap dinikahkan kapan saja. Kondisi demikian menyimbolkan sebuah ancaman yang membelenggu kebebasan kaum perempuan.

Kartini dan pengalamannya mewakili kondisi perempuan pada tataran lokal. Sementara dalam skala global, tidak kalah menarik bahwa protes terhadap dominasi patriarki semakin bergema di era milenium ketiga ini. Tak sedikit kaum perempuan mulai sadar menyuarakan hak-haknya, yang selama ini dikekang oleh sistem patriarki. Suara-suara itu menggema dalam berbagai kategori, misalnya gerakan perempuan, baik melalui protes langsung maupun melalui tulisan-tulisan bernas mengkritik sistem patriarki yang telah mengakar kuat.

Kisah “Jaka Tarub dan Tujuh Bidadari" memperlihatkan sebuah konteks klasik dalam masyarakat Jawa tradisional, bahkan sebagian besar tradisi masyarakat Indonesia umumnya, bahwa perempuan seringkali mengalami dilema dalam pilihan hidup, misalnya persoalan pernikahan. Dalam hal ini, tentang (terjebak) perjodohan yang cenderung bertentangan dengan keinginan mereka seperti, yang dialami Kartini. Karena ketidakbebasan ini, 
Kartini, dalam bukunya Habis Gelap Terbitlah Terang mengatakan: “Di dunia Jawa, cinta merupakan khayalan. Bagaimana seorang laki-laki dan seorang perempuan dapat saling mencintai kalau pertemuan pertama kalinya terjadi setelah mereka saling terikat oleh pernikahan sungguh-sungguh?"2 Beban pekerjaan rumah tangga pun dipandang sebagai sesuatu yang harus diemban dan wajib diterima begitu saja tanpa protes. Cerita rakyat ini membawa isu-isu yang menarik dan kompleks mengenai hubungan laki-laki dan perempuan dalam masyarakat patriarkal.

Eksplorasi pesan-pesan pembebasan ini diharapkan bisa dijadikan model merekonstruksi paradigma terhadap perempuan, sehingga tercipta relasi yang lebih baik untuk membangun dunia manusia menjadi lebih baik, daripada ngotot mempertahankan konsep tertentu yang cenderung otoriter eksploitatif.

\section{Kisah "Jaka Tarub dan Tujuh Bidadari”}

Rupa-rupanya, masalah penindasan dan gerakan kebebasan perempuan diabadikan dalam legenda "Jaka Tarub dan Tujuh Bidadari", yang kurang lebih memiliki enam varian yang berasal dari Tanah Jawa. Walaupun terdapat kemiripan dalam enam varian tersebut namun yang akan dipilih dan dianalisis adalah legenda yang "terdapat dalam Babad Tana Jawi (diterjemahkan oleh Sudibyo tahun 1980) karena dianggap masih asli, utuh, dan belum mengalami penyesuaian-penyesuaian". ${ }^{3}$

Untuk membahas lebih jauh gagasan yang hendak dibangun dalam diskursus ini, penulis perlu menampilkan kisah dari legenda bersangkutan, yang nantinya akan menjadi titik berangkat menggali pesan-pesan pembebasan. Kisah Jaka Tarub yang terdapat dalam Babad tersebut adalah sebagai berikut:

Suatu ketika, Jaka Tarub sedang berburu ke hutan (dengan alat tulup ${ }^{4}$ ) bertemulah dia dengan seekor burung yang elok warna bulunya. Dia sangat terpesona tetapi selalu melesat dari tulupannya. Suatu saat burung itu hinggap di pohon sini, dikejar hinggap lagi di pohon berikutnya. Begitu selalu hingga akhirnya masuk ke hutan lebat. Di tengah hutan ini terdapat sebuah telaga terkenal tempat mandi para bidadari. Pada suatu hari Selasa (Anggara Kasih) bidadari turun dari kahyangan lalu mandi di tempat itu. Jaka Tarub yang sudah lama menantikan kebenaran cerita itu, demi melihat para bidadari bertebaran di sekeliling telaga, dia segera bersembunyi. Bidadari beramai-ramai turun dan meloloskan bajunya lalu menceburkan diri berenang di dalam telaga biru. $\mathrm{Ki}$

2. Ibid., 20-21.

3. Robi Wibowo, Nalar Jawa Nalar Jepang (Yogyakarta: Gadjah Mada University Press, 2017), 24.

4. "Tulup" adalah sumpitan. Arti lainnya, senjata tradisional untuk berburu yang terbuat dari kayu meranti yang dilubangi, berpeluru potongan-potongan seperti lidi dari pelapah pohon enau yang berbentuk seperti mata panah yang disebut ancar. 
Jaka mengamatinya dengan mata yang tajam, ternyata memang bidadari itu elok rupanya. Dia berusaha menggaet salah satu pakaiannya dan menyembunyikan, dan tak seorang pun dari mereka melihat kejadian tersebut. Ketika dayang-dayang surga ini sedang riang gembira berenang di dalam telaga, Ki Jaka lalu menyentakkan batuk-batuk kecilnya. Setelah mendengar suara manusia, bidadari-bidadari itu segera berpakaian dan terbang ke angkasa. Tinggallah seorang dari mereka yang terbenam di pinggir telaga yang tak dapat pergi dari situ karena tak ada pakaian. Bidadari itu bernama Nawang Wulan. Jaka Tarub segera menghampirinya dan singkat cerita, Jaka Tarub sanggup memberi pakaian padanya asal sang dewi bersedia menikah dengan Jaka Tarub. Terdesak oleh keadaan, Nawang Wulan bersedia memenuhi Jaka Tarub, apa pun yang terjadi. Akhirnya Nawang Wulan dibawa pulang oleh Jaka Tarub dan nyai Janda ${ }^{5}$ amatlah girangnya.....Pada suatu hari Nawang Wulan hendak pergi ke sungai untuk mencuci pakaian bayi karena mereka sudah dikaruniai seorang bayi perempuan yang mungil, diberi nama Rara Nawangsih. Selama kepergiannya, pesan penting disampaikan kepada suami, yaitu sebagai suami jangan sekali-kali membuka tutup dandang tempat ia memasak nasi. Ini adalah pantangan. Tetapi Ki Tarub merasa heran, ingin tahu apa sebabnya ada pantangan yang begitu keras. Maka sesaat setelah istrinya pergi, sambil menggendong si kecil ki Tarub membuka tutup dandang. Dilihatnya sekarang bahwa dandang itu hanya berisi sebatang padi, jadi bukannya beras yang dimasak. Ini kiranya sebab hasil panen padi selumbung itu bertahun-tahun tak pernah habis. Setelah Dewi Nawang Wulan tiba dari perjalanannya mencuci di sungai, ia membuka masakan nasinya, menjadi amat terkejut karena di dalam kukusan, padi sebatang masih utuh. Nawang Wulan menuduh suaminya serong karena telah melanggar pantangannya. Ia berusaha hendak meninggalkan suaminya hari itu juga tetapi apa daya, kesaktiannya sudah hilang. Kini rahasia Nawang Wulan sudah terjabarkan, kegaibannya karena itu sudah hilang tidak dapat menanak nasi lagi dengan sebatang padi. Setiap pagi, ia harus menumbuk padi di lesung. Proses penanakan nasi berlangsung seperti umum terjadi. Dan dengan demikian padi selumbung juga lekas habis. Tak diduga bahwa di dalam lumbung padi itu disembunyikan pakaian kahyangan yang diambil oleh suaminya ketika para bidadari mandi di telaga. Nawang Wulan amatlah kesalnya, baju segera diambil dan dipakai, terasa kini kembali kesaktiannya. Nawang Wulan berpamit pada suaminya, bahwa kini tiba saatnya untuk berpisah, sudah dipastikan dirinya hendak kembali ke kahyangan. ${ }^{6}$

Kisah di atas akan mengantar pada tafsir teks, yang tentunya tidak lepas dari bingkai perempuan dan kebebasan. Namun tafsir atas kisah di atas akan didahului oleh gagasan mengenai latar belakang dan tujuan lahirnya gerakan feminisme.

\section{Gerakan Feminisme}

Sebelum lebih jauh membahas tafsir teks, terlebih dahulu akan

\footnotetext{
5. Nyai Janda adalah ibu angkat Jaka Tarub.

6. Robi Wibowo, Nalar Jawa, 24-26.
} 
dijelaskan gerakan feminisme namun tidak serta-merta dimengerti sebagai penjelasan tentang teologi feminisme secara terperinci dan mendalam, melainkan sebatas mengambil poin-poin penting dari munculnya gerakan perempuan sebagai panduan untuk menafsir teks "Jaka Tarub dan Tujuh Bidadari". Secara sederhana, feminisme adalah sebuah gerakan untuk mengakhiri seksisme, eksploitasi, dan penindasan seks. ${ }^{7}$ Bell Hooks berkata,

From its earliest inception feminist movement was polarized. Reformist thinkers chose to emphasize equality. Revolutionary did not want to simply to alter the existing system so that woman would have more right. We wanted to transform that system to bring an end to patriarchy and sexism. The vision of "women's liberation" which captured and still holds the public imagination was the one representing women as wanting what man had. Changes in our nation's economy, economic depression, the loss of jobs, etc, made the climate ripe for our nation's citizens to accept the notion of gender equality in the workforce. ${ }^{8}$

Ungkapan Hooks menunjukkan bahwa, meskipun dari awal ada polarisasi pemahaman tentang gerakan feminisme dari para pemikir, namun akhirnya diterima satu gagasan, yakni tentang kesetaraan (keadilan) gender yaitu mengubah sistem untuk mengakhiri patriarki dan seksisme dalam ruang publik agar kaum perempuan juga dapat memiliki hak lebih sebagaimana yang dimiliki laki-laki. Dengan kata lain, gerakan feminisme ini tidak hanya sekadar mereformasi tetapi juga merekonstruksi kembali sistem dalam masyarakat. ${ }^{9}$

Sarah Gamble dalam Postfeminism ${ }^{10}$ mengatakan bahwa gerakan perempuan ini dimotivasi oleh karena adanya keyakinan bahwa perempuan (murni dan semata-mata karena mereka perempuan) diperlakukan secara tidak adil dalam masyarakat yang diorganisasikan untuk memprioritaskan sudut pandang dan kepentingan laki-laki. Masyarakat yang "memprioritaskan sudut pandang dan kepentingan laki-laki", dalam pemikiran Weedon, disebut sebagai masyarakat patriarkis. ${ }^{11}$ Dengan demikian gerakan perempuan ini dimaksudkan untuk menentang struktur patriarki dalam masyarakat. Gamble, sebagaimana Hooks, memiliki satu dasar pemikiran yang sama perihal gerakan perempuan atau gerakan feminisme tersebut.

7. Bell Hooks, Feminism is for Everybody: Passionate Politics (New York: Routledge, 2014), 1.

8. Ibid., 4.

9. Letty M. Russell, ed., Feminist Interpretation of The Bible (London: Westminster John Knox Press, 1985), 28.

10. Sarah Gamble, "Postfeminism," The Routledge Companion to Feminism and Postfeminism, ed. Sarah Gamble (London and New York: Routledge, 2006), vii.

11. Ibid., 3 . 
Sejalan dengan kedua pemikir feminis di atas, Schussler Fiorenza pun mengatakan hal yang serupa dengan sedikit spesifikasi, bahwa "feminisme tidak hanya peduli tentang gender tetapi juga tentang ras, kelas, heteronormativitas, dan imperialisme. Ini adalah keprihatinan tentang hubungan kekuasaan dominasi kyriarkal. ${ }^{12}$ Pokok persoalan yang hendak disampaikan oleh Fiorenza adalah gerakan perempuan lahir dari sebuah komitmen untuk melawan kekuatan dominasi maskulinitas.

Gerakan feminisme, sebagai sebuah gerakan sosial, memiliki beberapa "gelombang", yakni gelombang pertama, sekitar tahun 1792, ketika Mary Wollstonecraft mempertahankan hak-hak perempuan, atau 1848 dalam acara konvensi hak-hak perempuan pertama di Seneca Falls (New York), hingga 1920 ketika perempuan Amerika Serikat diberi hak suara memilih. ${ }^{13}$ Gelombang kedua adalah periode aktivisme yang dimulai pada 1960-an saat acara Komisi Presiden Kennedy tahun 1961 tentang Status Perempuan yang dipimpin oleh Esther Peterson dan saat terbitnya buku Betty Friedan, The Feminine Mystique (1961). ${ }^{14}$ Feminisme gelombang ketiga mengacu pada gagasan dan tindakan perempuan dan orang-orang yang akan menghabiskan sebagian besar hidup mereka di abad kedua puluh satu. ${ }^{15}$

Dalam konteks Asia Kwok Pui Lan dalam bukunya Discovering the Bible in the Non-Biblical World memberi gambaran tentang usaha orang Asia, secara khusus orang Kristen Cina, yang mulai sadar untuk menginterpretasikan kembali makna Kitab Suci, bukan hanya bagi orang Kristen melainkan juga bagi semua warga masyarakat Cina. Contohnya, mereka membandingkan istilah agape dalam Kitab Suci dengan istilah benevolence dalam sastra klasik Cina. Juga membandingkan ajaran moral Yesus dengan ajaran dalam tradisi Konfusius. Perhatian utama melalui reinterpretasi biblika ini adalah keselamatan bersama. Oleh karena concern tersebut, pesan biblika coba dipertautkan dalam konteks keseharian mereka. Di pertengahan tahun 1930, sebagai bentuk antisipasi perkembangan teologi pembebasan satu abad setelahnya, Wu Yaozhong mereinterpretasi Yesus sebagai seorang revolusioner, pemegang keadilan dan seorang yang memperjuangkan hakhak bagi mereka yang tertindas. ${ }^{16}$

12. Elizabeth Schussler Fiorenza, "The will to choose or to reject," Feminist Interpretation of the Bible, ed. Letty M. Russell (Philadelphia: The Westminster Press, 1985), 127.

13. George Ritzer, The Blackwell Encyclopedia of Sociology (Massachusetts: Blackwell Publishing, 2007), 1666.

14. Ibid.

15. Ibid.

16. Lih. Kwok Pui Lan, Discovering the Bible in the Non-Biblical World (New York: Orbis Books, 1995), 11. 
Dengan melihat konteks gerakan feminisme, baik yang berkembang di Amerika maupun di Asia, secara khusus di Cina, boleh dikatakan bahwa arus paling dasar dari gerakan perempuan adalah memperjuangkan hak-hak mereka, menuntut keadilan dalam masyarakat, terutama karena kuatnya dominasi laki-laki. Bahkan jika mau merunut jauh ke belakang, pandangan tentang gerakan perempuan dilatarbelakangi oleh tradisi patriarki yang dimulai sejak zaman Yudaisme dan tradisi Kristen terutama dalam penafsiran biblika yang sangat bernuansa maskulin. Imaji-imaji Tuhan yang sangat maskulin (sementara imaji-imaji Tuhan yang feminin diabaikan bahkan walaupun ada, tidak banyak jumlahnya) dapat ditemukan, misalnya dalam salah satu doa populer tradisi Yudaisme dan Kristen yang menyebut Tuhan sebagai Bapa dan Raja sekaligus (dalam Bahasa Ibrani: Avinu Malkeinu) ${ }^{17}$ Tafsir ortodoksi ini kemudian menjadi cikal-bakal bergemanya gerakan perempuan dalam berbagai kategori di berbagai bangsa.

Pada pertengahan abad ke-20 muncul beberapa gerakan kenabian, antara lain teologi pembebasan yakni memihak pada kaum miskin yang ditindas oleh tatanan ekonomi modern, teologi feminis yang berusaha memikirkan kembali teologi melalui sudut pandang perempuan yang tertekan, dan ekoteologi yang memikirkan pemeliharaan alam ciptaan Allah. Ketiga aliran ini melawan dosa struktural yaitu tatanan yang menindas dan memiskinkan golongan tertentu. Patriarki ditentang karena meremehkan kaum perempuan, serta menggunakan alam sebagai sumber kekayaan bagi manusia yang bermodal dan berilmu. ${ }^{18}$

Gerakan perempuan tidak hanya berkembang di masyarakat bangsa lain melainkan juga terekam dalam sejarah bangsa Indonesia, dan biasanya lebih dikenal dengan istilah emansipasi. Para pejuang perempuan seperti Raden Ajeng Kartini, Cut Nyak Dhien, Nyi Ageng Serang, Maria Walanda Maramis, dan Dewi Sartika, adalah contoh dari beberapa perempuan yang peduli terhadap hak-hak kaum mereka. Meskipun dalam konteks melawan penguasa kolonial namun tidak dipungkiri bahwa hakikat dari perlawanan para perempuan tangguh ini adalah cita-cita akan sebuah kebebasan secara fisik dan psikis. Kartini, misalnya, mengamati penderitaan perempuan (Jawa) yang harus dipingit, tidak bebas dalam menuntut ilmu, serta adat yang mengekang kebebasan perempuan. Kartini juga menyinggung agama, misalnya larangan untuk berpoligami bagi seorang perempuan dan perihal membaca dan menghafal Kitab Suci tanpa perlu dipahami.

17. Bambang Sugiharto, "Tuhan dan Seribu Imajinya", dalam Agama dan Kesadaran Kontemporer, Bartolomeus Samho, dkk, Peny. (Yogyakarta: Kanisius, 2019), 173.

18. Marie Claire Barth Frommel, Hati Allah Bagaikan Hati Seorang Ibu: Pengantar Teologi Feminis (Jakarta: BPK Gunung Mulia, 2006), 14. 
Sementara di sisi lain, laki- laki (Jawa) digambarkan sebagai manusia sempurna jika memiliki wisma (rumah), perempuan (perempuan), turangga, kukila (burung/piaraan), dan curiga (keris sebagai simbol kesaktian/kekuasaan). Jika mengamati konsep "kesempurnaan seorang laki-laki" dalam budaya Jawa, secara implisit menunjukkan status perempuan yang, boleh dikatakan, hanya sebagai masyarakat kelas dua atau ekstremnya sejajar dengan barang-barang yang harus dimiliki laki-laki. ${ }^{19}$

Meriapnya gerakan perempuan, baik pada tataran global maupun lokal ini, disebabkan "dalam patriarki (pater: bapak, arche: asal mula yang menentukan) laki-laki berkuasa atas semua anggota masyarakat yang lain dan mempertahankan kuasa itu sebagai milik yang "sah", baik melalui lembaga masyarakat, harta maupun pengetahuan".${ }^{20}$ Dengan kata lain, "dalam masyarakat seperti ini, pandangan androsentris (andros: laki-laki, sentris: berhubung dengan inti) menentukan budaya, yakni segala peristiwa dilihat dari sudut pandang laki-laki" ${ }^{21}$ Dominasi laki-laki dalam masyarakat ini menjadi landasan perlawanan perempuan agar mereka pun bisa diperlakukan sebagai citra Allah yang utuh yang boleh berekspresi dalam ruang publik.

Karena itu, menurut reinterpretasi biblika dan cerita rakyat populer bagi kaum feminis menjadi bagian penting dari upaya pembebasan yang mengombinasikan iman dan kultur setempat. Hermeneutik "kecurigaan" adalah pisau bedah bagi teolog feminis untuk menginterpretasi Kitab Suci dan cerita-cerita rakyat. Bagi teolog feminis, Kitab Suci dan cerita rakyat cenderung dibangun atas pola pikir patriarkat, dan dengan demikian semakin mengukuhkan dominasi laki-laki dalam masyarakat. Gerakan perempuan ini, atau dalam beberapa kategori sangat teologis yang kemudian dikenal sebagai teologi feminisme, "meskipun terdapat sejumlah aliran dengan situasinya yang berlainan, mereka setujuan, yakni mencari dan membela martabat manusia serta kesetaraan semua perempuan dan laki-laki" ${ }^{22}$ Artinya gerakan perempuan juga peduli terhadap isu-isu secara menyeluruh (di bidang politik, agama, sosial, dan budaya) pada tataran lokal maupun global, apalagi di masa sekarang ini yang tak henti-hentinya "memproduksi" persoalan-persoalan, seperti sex commercial industries, human trafficking, dan children sex abuse. Atau seperti yang ditegaskan, "violence against woman and girls continues unabated in every continent, country and culture and is a problem of pandemic propotion. At least one out of every three woman around the world has

19. Christina S. Handayani \& Ardhian Novianto, Kuasa Perempuan Jawa (Yogyakarta: LKiS Yogyakarta, 2004), ix.

20. Frommel, Hati Seorang Ibu, 8-9.

21. Ibid., 9.

22. Ibid., 16. 
been beaten, coerced into sex, or otherwise abused in her lifetime (UNIFEM 2017). ${ }^{23}$

Singkatnya, struktur patriarki di dalam hampir semua bidang kehidupan membawa dampak pada kesadaran kaum perempuan untuk berjuang demi kesetaraan gender, baik secara intelektual maupun praktis.

\section{Menafsir Pesan Pembebasan}

Peristiwa "kejatuhan manusia" menurut kaum feminis adalah peristiwa terjebaknya perempuan dalam dominasi laki-laki (patriarki) di dalam "hampir" semua lini kehidupan. Kata "hampir" menyiratkan "tidak semua simbol-simbol, baik dari agama-agama maupun sosial budaya, kontra terhadap perempuan. Masih banyak simbol-simbol berbicara mengenai nilai-nilai keharmonisan, keadilan, dan egalitarian" ${ }^{24}$ Namun perlu diakui bahwa kenyataannya tidak sekuat kebalikannya (dominasi patriarki).

Sementara itu, peristiwa kejatuhan dalam legenda Jaka Tarub dan Tujuh Bidadari adalah peristiwa ketidakberdayaan kaum perempuan yang diwakili oleh Nawang Wulan. Momen Jaka Tarub melihat tujuh bidadari yang sedang mandi di telaga secara implisit menempatkan laki-laki pada tingkat superior dan perempuan pada tataran yang inferior. Momen melihat menegaskan secara simbolik hak penuh Jaka Tarub (laki-laki) untuk menguasai perempuan (tujuh bidadari) sesuka hati. Melihat boleh ditafsir sebagai menikmati tubuh. Di sini tubuh menjadi alat atau proses pengalaman bersinggungan, yaitu menjadi kendaraan bagi kesadaran pada pikiran untuk melakukan tindakan tertentu, dan proses tersebut terealisasi dalam bentuk tindak lanjut Jaka Tarub dengan mengambil pakaian Nawang Wulan. Tubuh dalam konteks ini menjadi bahasa simbolik pengalaman berkesadaran untuk mencapai tujuan.

Gambaran ketidakberdayaan perempuan pun tersimbolisasi melalui momen pakaian Nawang Wulan yang dicuri oleh Jaka Tarub. "Mengambil" dalam konteks cerita adalah tindakan untuk menguasai, membatasi kebebasan, dan membuat menjadi tidak berdaya. Sementara keadaan Nawang Wulan yang telanjang merupakan penggambaran yang sangat jelas tentang rentannya perempuan, sehingga Jaka Tarub (sebagai simbol laki-laki) dapat mengendalikannya. Ketelanjangan Nawang Wulan tersebut semakin memudahkan upaya represif Jaka Tarub (kaum laki-laki) mengeksploitasi ruang gerak Nawang Wulan (kaum perempuan) untuk berekspresi. Kondisi Nawang Wulan yang berada dalam kesendirian akibat ditinggalkan keenam

23. Janet A. Kourany, Philosophy of Science After Feminism (New York: Oxford University Press, 2010), 3.

24. Minggus M. Pranoto, "Selayang Pandang tentang Teologi Feminis dan Metode Berteologinya", Jurnal Abdiel 2, no. 1 (April 2018): 4. 
bidadari lain boleh dibaca sebagai bentuk ketidakpedulian terhadap sesama perempuan dan menempatkannya seakan-akan menjadi -- meminjam istilah Naomi Wolf dan Katie Roiphe -- victim feminism, perempuan yang menjadi korban karena ketidakberdayaannya melawan kekerasan patriarki, bahkan untuk menyelamatkan dirinya sekalipun. ${ }^{25}$

Keinginan Jaka Tarub untuk memiliki Nawang Wulan dengan mengambil pakaiannya merupakan representasi dari upaya yang yang dilakukan kaum laki-laki untuk menekan perempuan. Perempuan yang telanjang adalah perempuan yang tidak berdaya. Dalam cerita, Nawang Wulan tidak mempunyai pilihan lain selain menerima ajakan dari Jaka Tarub. Nawang Wulan sebagai seorang bidadari terjebak dalam situasi yang mengharuskan dia mencari cara untuk bertahan hidup. Muatan simbolik dari momen ini adalah kekuatan laki-laki membatasi kebebasan perempuan dan hak-haknya menentukan jalan hidup secara mandiri.

Tawaran tinggal bersama (bisa diinterpretasikan sebagai tawaran menikah) dipandang sebagai suatu cara bertahan hidup di dalam dunia yang asing bagi seorang bidadari. Tawaran tinggal bersama menyiratkan makna adanya upaya patriarkal mempertegas kekuasaannya, yang dilakukan terhadap individu perempuan agar ia (dipaksa) tunduk pada kepentingan laki-laki. Kepentingan laki-laki dalam cerita, tidak lain adalah upaya Jaka Tarub untuk memiliki Nawang Wulan. Hilangnya pakaian kahyangan (atau dalam versi lain, selendang) menandakan hilangnya identitasnya sebagai bidadari. Pakaian yang diberikan Jaka Tarub menandai identitas yang baru, sebagai makhluk duniawi, yakni seorang istri dan ibu.

Lazimnya, cerita rakyat yang berbicara menyinggung pernikahan digambarkan sebagai puncak kebahagiaan perempuan, sedangkan dalam cerita ini pernikahan merupakan suatu kondisi keterpaksaan yang mengekang kebebasan perempuan. Bahwa Nawang Wulan mau menikah dengan Jaka Tarub atas dasar cinta, dapat diragukan dan dicurigai. Kondisi ini sebetulnya, kurang lebih mewakili budaya dan tradisi sebagian masyarakat Indonesia perihal pernikahan, melalui perjodohan. Memang tidak semua, tetapi cukup banyak adat yang "ngotot" mempertahankan proses membangun kehidupan berumah tangga melalui tahapan perjodohan. Perjodohan membuat kebebasan eksistensial perempuan dibatasi oleh kesepakatan sosial, bahkan jika ditelusuri lebih jauh ke belakang, perjodohan tidak lain merupakan anak kandung feodalisme. Feodalisme merupakan sistem sosial yang senantiasa mengagung-agungkan jabatan atau pangkat. Kartini adalah bukti nyata korban dari budaya feodal yang 
ada dalam masyarakat Indonesia di masa lalu karena ia dijodohkan bukan dengan lelaki pilihannya, melainkan dengan seorang yang memiliki jabatan atau pangkat (dan karenanya terpandang dalam masyarakat) yaitu Bupati Rembang.

Tokoh Nawang Wulan juga mewakili perempuan lokal yang dituntut melakukan mukjizat. Hanya sebatang padi dapat diolah menjadi sebakul nasi. Demikian juga perempuan (Jawa) pada umumnya dituntut bekerja secara ajaib. Selain bekerja membersihkan rumah, terdapat tugas lain, yaitu menyiapkan makanan dan mengurus suami dan anak. Apalagi ditambah dengan para perempuan yang juga bekerja di pabrik atau perusahaan. Keingintahuan Jaka Tarub (untuk melihat isi dandang) mewakili kecemasan maskulin terhadap kekuatan feminin yang potensial. Mantra bidadari di luar kuasa laki-laki dianggap sebagai ancaman potensial bagi otoritas maskulin. Pemutusan mantra akibat pelanggaran janji oleh Jaka Tarub (membuka tutup dandang nasi) menunjukkan penegasan kekuatan patriarkal dan makin kuatnya kontrol laki-laki atas perempuan. Oleh karena pelanggaran janji ini Nawang Wulan mewakili perempuan yang menderita fisik dan emosional. Namun laki-laki dalam dunia patriarki digambarkan tidak peduli dengan penderitaan perempuan. Ketidakpedulian laki-laki terhadap perempuan juga bisa dilihat sebagai ketidakpeduliannya terhadap lingkungan tempat perempuan bekerja keras, atau dengan kata lain, hilangnya penghargaan atas eksistensi perempuan dalam ruang sosial secara spesifik pada tataran moral. Budaya komersial yang mengeksploitasi perempuan dan anak-anak merupakan salah satu dari sekian banyak contoh kekeliruan cara pandang atas nilai hakiki perempuan.

Ketidakpedulian laki-laki (Jaka Tarub) ini membuka mata kaum perempuan yang dikisahkan dengan Nawang Wulan yang menemukan pakaiannya di lumbung padi. Peristiwa penemuan ini juga dapat dilihat sebagai peristiwa yang membangkitkan kesadaran perempuan tentang ke-diri-annya dan hakhak mereka sekaligus pelecut motivasi untuk bebas dari belenggu dominasi patriarki. Momen menemukan pakaian dibaca sebagai momen menemukan kembali dirinya yang sejati. Representasi Nawang Wulan dalam cerita merupakan ajakan bagi perempuan menemukan kesadaran untuk bebas. Secara spesifik kebebasan ini adalah kebebasan dari belenggu fisik dan psikis dari budaya patriarki yang terlampau dominan dan membatasi ekspresi perempuan. Dalam perspektif feminis, peran-peran manusia (laki-laki dan perempuan) dalam masyarakat dipandang timpang (tidak egaliter). Artinya, konstruksi sosial selama ini dianggap sangat berpihak kepada laki-laki dan 
pada saat yang sama menyudutkan kaum Hawa. ${ }^{26}$ Menurut kaum feminis, hegemoni laki-laki atas perempuan ini memperoleh legitimasi dari nilainilai sosial, agama, hukum negara, dan sebagainya, dan tersosialisasi secara turun-temurun dari generasi ke generasi. ${ }^{27}$

Oleh karena adanya ketimpangan dalam isu gender ini, di mana budaya patriarki mendominasi di segala lini kehidupan, maka tak bisa dipungkiri bahwa hampir semua keputusan dan penentuan kepada akses kehidupan dikuasai oleh kaum laki-laki. Ini terlihat melalui motif gerakan perempuan. Kondisi mereka yang dikekang oleh kultur patriarki memosisikan perempuan sebagai kaum marginal, berada di kelas kedua, sebagaimana gambaran perempuan Jawa yang hanya disetarakan dengan barang-barang yang harus dimiliki laki-laki.

\section{Analisis Perspektif Teologis}

Karena akar rumput gerakan perempuan menuntut kesetaraan adalah persoalan ortodoksi, yaitu konteks biblika yang disinyalir oleh kaum perempuan telah muncul sejak awal era Yudaisme dan Kristianitas, maka analisis ini pun tak akan pernah lepas seutuhnya dari konteks biblika. Dengan kata lain, konteks teologis sebagai pelecut munculnya teologi (eko)feminisme perlu secara ringkas dibahas di sini. Dalam Kitab Hukum Kanonik 1055, Gereja Katolik mengatakan, "seorang laki-laki dan seorang perempuan membentuk di antara mereka persekutuan seumur hidup dengan mengikat diri dalam perjanjian perkawinan. Perjanjian ini mengandaikan adanya cinta di antara mereka." Perkawinan Nawang Wulan dan Jaka Tarub dalam cerita rakyat ini diragukan atas dasar cinta. Nawang Wulan menikah karena keterpaksaan. Cerita rakyat ini juga menunjukkan perasaan tidak aman Nawang Wulan karena tidak ada laki-laki yang melindunginya. Sehingga, mungkin menyetujui tawaran tinggal bersama menjadi satu-satunya cara menghindarkan diri dari risiko yang lebih buruk di tengah ketidakberdayaannya, lebih-lebih dalam keadaan tanpa busana.

Keberadaan bidadari dalam cerita rakyat adalah perempuan-perempuan yang memiliki kesaktian atau kekuatan ilahi. Nawang Wulan tidak hanya mewakili perempuan Jawa, melainkan juga perempuan pada umumnya. Nawang Wulan dilihat sebagai simbol kehidupan dan kesuburan, sebagai sumber kemakmuran. Hal ini ditandai dengan mukjizat yang dapat dilakukan. Ketidakpedulian manusia yang diwakili ketidakpedulian Jaka Tarub merupakan akar penderitaan yang dialami perempuan dan alam (di

26. Siti Muslikhati, Feminisme dan Pemberdayaan Perempuan dalam Timbangan Islam (Jakarta: Gema Insani Press, 2004), 30.

27. Ibid. 
Jawa). Keingintahuan juga merupakan kunci dari kebebasan. Seperti Kartini yang mempertanyakan mengapa Kitab Suci harus dihafalkan dan dilafalkan tanpa wajib untuk dipahami. ${ }^{28}$ Pelanggaran perjanjian yang dilakukan Jaka Tarub dapat direfleksikan sebagai hukuman yang dikenakan pada laki-laki dan perempuan (Kej. 3:16-19) dan juga efek dosa terhadap alam akibat melanggar janji kepada Allah (Yahwe). Kutukan Allah (Yahwe) terhadap alam mengakibatkan manusia (Adam-Hawa) menderita secara jasmani dan rohani, bekerja keras membanting tulang mengolah tanah untuk bertahan hidup. Namun satu hal yang juga perlu dikritik adalah, pelanggaran perjanjian dengan Allah tidak serta-merta menuduh perempuan sebagai penyebab utama, karena pada saat yang sama perempuan terikat dalam satu kesatuan hidup dengan laki-laki. Karena itu, kesalahan perempuan serentak merupakan kesalahan laki-laki. Dengan demikian tidak serta-merta menuduh secara mutlak perempuan (Hawa) sebagai sumber "kejatuhan" manusia ke dalam dosa. Mengapa tidak perlu buru-buru meletakkan perempuan (Hawa) secara subordinatif dalam konteks biblika ini karena, mungkin, tradisi tafsir biblika yang terlampau bernuansa maskulin dan dalam peristiwa Taman Eden perempuan (Hawa) tidak sendirian.

Mukjizat Nawang Wulan menjadi tidak berlaku lagi akibat tidak adanya (lagi) berkat dari Dewi Sri, yakni dewi padi, seorang perempuan yang dalam mitologi Jawa merupakan representasi dari Ilahi yang feminin. Dalam narasi, tersirat pesan bahwa Jaka Tarub ingin juga berusaha menyingkirkan dominasi gambaran Ilahi yang feminin yang disimbolkan dengan padi. Padi dalam tradisi Jawa selalu identik dengan Dewi Sri. Metafora Tuhan yang sangat bernuansa maskulin menyingkirkan aneka imaji lainnya tentang Tuhan sekaligus menunjukkan superioritas laki-laki di hadapan perempuan. Misalnya "pengalaman-pengalaman dasariah dalam perhubungan dengan kehidupan, seperti tentang kelahiran kehidupan baru, kesuburan, pemeliharaan, komitmen tanpa pamrih, pengalaman tentang "kerahiman" kasih sayang tanpa batas sangat kuat berkorelasi dengan manusia dalam kaitannya dengan figur " $\mathrm{ibu}{ }^{\text {"29 }}$ sehingga tidak cukup keliru untuk menegaskan Tuhan yang feminin bahkan dalam Katekismus (panduan Iman Katolik) ditegaskan bahwa Tuhan pada dasarnya tidak bergender..$^{30}$ Hampir serupa dengan pemahaman ini, Mary Daly menolak konsep eksklusivitas Tuhan sebagai laki-laki. Ia menolak pandangan yang

28. Ismail Kusmayadi, Think Smart Bahasa Indonesia (Bandung: Grafindo Media Pratama, 2007$), 20$.

29. Sugiharto, "Tuhan dan Seribu Imajinya", 171.

30. David Bordwell, Catechism of the Catholic Church (London \& New York City: Continuum International Publishing, 2002), 84. 
mengatakan God is male and male is God. ${ }^{31}$ Jika dibandingkan antara Dewi Sri, pengalaman kehidupan yang berkaitan dengan figur ibu, pengertian Tuhan yang tidak bergender (Katekismus) dan pemikiran Mary Daly, bisa ditarik benang merah jika gerakan perempuan memiliki argumen yang cukup kuat untuk dipahami. Artinya, memang metafora Tuhan pun sangat dimungkinkan untuk dibingkai dalam nuansa feminin. Namun karena upaya represif dari laki-laki (secara simbolik direpresentasikan oleh Jaka Tarub melalui tindakannya melanggar pantangan yang diberikan Nawang Wulan) imaji Ilahi yang feminin tersebut dibungkam oleh metafora Tuhan yang maskulin. Oleh sebab "tatanan patriarkal Kitab Suci, tradisi gerejawi dan teologi yang sedemikian kebal, sehingga untuk memberikan kepada perempuan tempat yang layak di dunia laki-laki dibutuhkan iman yang utopis, yaitu iman yang menemukan Allah dalam keakanan, suatu dorongan yang mengubah apa yang kini ada." 32

Pada sisi lain, legenda "Jaka Tarub dan Tujuh Bidadari" juga berbicara tentang eco-feminism. Perempuan dianalogikan sebagai bumi, yang tidak lain adalah tubuh Allah sendiri sebagaimana dibicarakan juga oleh beberapa filsuf dan teolog pada masanya masing-masing seperti Sallie McFague (seorang teolog feminis abad ke-20), Spinoza yang berbicara tentang konsep panteisme (abad ke-16), dan Meister Eckhart (dalam tradisi mistik kristiani pada abad ke-13), bahwa bumi adalah modus atau properti Tuhan, dan Tuhan sendiri adalah esensi atau inti terdalam dari segala sesuatu. Meminjam istilahnya Ibn 'Arabi, wahdat al-wujud, Tuhan merasuki segala hal dan adalah esensi segala hal. Konteks "bumi atau dunia atau semesta sebagai tubuh Allah" juga memberikan analogi-analogi hubungan antara Allah dengan dunia ini dan oleh para teolog ekofeminis.

Bumi selalu memberi kehidupan pada manusia dan ciptaan lain. Bumi adalah lambang kehidupan, lambang kesuburan, dan lambang cinta. Sama halnya dengan perempuan yang menjadi lambang kehidupan, kesuburan dan cinta. Maka dominasi Jaka Tarub terhadap Nawang Wulan bisa dibaca sebagai simbol ketidakpedulian, keserakahan, dan kurangnya tanggung jawab terhadap bumi, terhadap ibu, perempuan.

\section{Rekonstruksi Paradigma}

Rekonstruksi cara pandang dimaksudkan sebagai upaya membaharui pemahaman dan pemaknaan terhadap eksistensi perempuan dalam

31. Mary Daly, Beyond God the Father: Toward a Philosophy of Women's Liberation (Massachusetts: Beacon Press, 1973), 20.

32. Letty M. Russell, Household of Freedom, Authority in Feminist Theology (Philadelphia: Westminster Press, 1987), 17. 
keseharian. Meskipun isu gender selalu menjadi pembicaraan yang tak akan pernah berhenti, namun setidaknya subordinasi yang diletakkan dalam relasi antara laki-laki dan perempuan mesti segera dibenahi, menuju ke arah yang lebih positif. Cara pandang adalah titik tolak, karena itu perlu direkonstruksi. Misalnya dalam narasi cerita dikatakan bahwa "Nawang Wulan menjadi sepenuhnya manusia biasa. Ia harus bersusah-payah mengambil padi di lumbung dan menumbuknya sebelum memasaknya menjadi nasi" Pertanyaan yang harus diletakkan pada pernyataan ini adalah di mana Jaka Tarub setelah keadaan rumah tangganya berubah akibat pelanggarannya sendiri? Kondisi Nawang Wulan yang jelas-jelas menggambarkan konteks subordinasi dalam persoalan gender. Nawang Wulan yang sebetulnya adalah korban justru harus menanggung kesalahan Jaka Tarub.

Di sini, jelas terlihat interpretasi bahwa perempuan (Hawa) diciptakan sesudah atau sebagai penolong laki-laki (Adam) terwakili secara simbolik oleh kondisi Nawang Wulan yang harus bersusah-payah mengambil padi di lumbung dan menumbuknya sebelum memasaknya menjadi nasi. Konteks biblika perihal perempuan (Hawa) diciptakan setelah laki-laki (Adam) dimaknai secara keliru, sehingga seolah-olah posisi perempuan menjadi lebih rendah. Konteks berpikir tentang posisi perempuan yang lebih rendah ketimbang laki-laki, bisa ditolak. Konteks biblika "penciptaan" tidak dimaksudkan untuk melanggengkan subordinasi terhadap perempuan. Paradigma tentang perempuan mesti dipahami sebagaimana memahami laki-laki, karena perempuan dalam terminologi penciptaan, diciptakan dari bagian terpenting tubuh laki-laki (tulang rusuk) seperti pemahaman dalam kultur Jawa yakni "perempuan Jawa sebagai konco wingking sekaligus garwo (sigaraning nyawa/belahan hati). ${ }^{33}$ Konsep kultur Jawa mengenai perempuan ini menyiratkan makna kesejajaran antara laki-laki dan perempuan, karena ketika menjadi suami-istri berarti telah menjadi satu tubuh. (bdk. Mat. 19:6 Demikianlah mereka bukan lagi dua melainkan satu.)

Kultur Jawa, konteks Penciptaan, dan juga Matius 19:6 memiliki kesejajaran makna dengan surat an-Nisaa':1 yang mengatakan, Hai sekalian manusia, bertakwalah kepada Tuhanmu yang telah menciptakan kamu dari diri yang satu, dan daripadanya Allah menciptakan isterinya, dari keduanya Allah memperkembangbiakkan laki-laki dan perempuan yang banyak. ${ }^{34}$ Ketiga perspektif di atas berbicara tentang tubuh, tubuh yang satu. Dalam perspektif teologis, tubuh menandakan kehadiran Ilahi. Melalui tubuh, Allah yang tidak terlihat

33. Handayani dan Novianto, Kuasa Perempuan Jawa, 26.

34. Muslikhati, Feminisme, 11. 
menjadi terlihat. ${ }^{35}$ Tubuh menjadi tanda nyata kehadiran Allah. Tubuh, bagi Yohanes Paulus II, adalah sebuah teologi. Bagi Yohanes Paulus II, tubuh merupakan sakramen. ${ }^{36}$

Sakramen merupakan sebuah tanda yang terlihat, terbentuk dalam diri manusia, sejauh manusia adalah sebuah tubuh, melalui tanda maskulinitas dan femininitas yang terlihat. Tubuh, sesungguhnya, dan hanya tubuh, mampu membuat terlihat apa yang tidak terlihat: yang spiritual dan yang ilahi. Tubuh telah diciptakan untuk menyalurkan ke dalam kenyataan dunia yang terlihat misteri yang tersembunyi sejak awal dalam diri Allah, dan karenanya tubuh menjadi tanda bagi misteri itu. ${ }^{37}$

Rekonstruksi cara pandang juga dapat dilihat dalam (narasi) versi lain legenda "Jaka Tarub dan Tujuh Bidadari" perihal kebulatan tekad Nawang Wulan untuk kembali ke kahyangan sekalipun diintervensi oleh Jaka Tarub. "Kebulatan tekad" menyiratkan potret kesadaran Nawang Wulan (kaum perempuan) perihal pentingnya menyuarakan hak-hak mereka akan sebuah kebebasan. Perempuan tentu berhak untuk memperjuangkan prinsip egaliter karena pada hakikatnya perempuan secara rohani, sebagaimana laki-laki, merupakan "gambar dan rupa Allah" sekaligus ciptaan paling istimewa di hadapan ciptaan-ciptaan lain. Oleh karena keduanya adalah citra Allah tadi, maka secara langsung menjadi rekan kerja Allah di dunia untuk menciptakan dunia yang lebih baik. Keduanya pun secara serentak terlibat dalam pertumbuhan alam semesta ini dan sama-sama memiliki potensi untuk berkembang maju dengan segala kriteria yang dimiliki sebagai makhluk alam, makhluk bermoral, makhluk religius, dan makhluk sosial.

Jika ditelaah secara mendalam pun, "patriarki tidak alamiah, apalagi merupakan ketentuan Tuhan. Patriarki terjadi dalam sejarah melalui proses sosialisasi yang panjang, karena itu bisa diakhiri dan menggantikannya dengan budaya masyarakat yang lebih adil bagi seluruh ciptaan." ${ }^{38}$ Mungkin akan sangat sulit, karena patriarki sudah menjadi sebuah struktur peradaban, dari generasi ke generasi, namun bukan berarti mutlak gagal. Gerakan perempuan sedang berproses untuk itu, untuk mengubah sistem patriarki supaya menemukan keseimbangan dalam dunia peradaban

35. Yesus Kristus disebut Sang Sabda yang menjadi daging. "Firman itu bersama-sama dengan Allah dan Firman itu adalah Allah" (Yoh. 1:1).

36. Deshi Ramadhani, Lihatlah Tubuhku: Membebaskan Seks bersama Yohanes Paulus II (Yogyakarta: Kanisius, 2009), 21-22.

37. Lih. pokok ke-4 dalam Audiensi Umum Paus Yohanes Paulus II pada Rabu, 20 Februari 1980. Pope John Paul II, “Man Enters the World as a Subject of Truthand Love" EWTN, 20 Februari 1980, https://www. ewtn.com/library/PAPALDOC/jp2tb18.htm (diakses tanggal 28 Januari 2020).

38. Asnath Niwa Natar, Ketika Perempuan Berteologi: Berteologi Feminis Kontekstual (Yogyakarta: Taman Pustaka Kristen, 2012), 28. 
manusia.

\section{Kesimpulan}

Perempuan adalah imago Dei seperti halnya laki-laki, sehingga tidak ada alasan untuk memperlakukan mereka secara tidak sempurna seperti citra Allah, teman sepadan (Kej. 2:18). Mereka tidak hanya sebatas menjadi seorang "penolong", tetapi lebih dari itu sebagai "sigaraning nyawa" (separuh jiwa) laki-laki. Pengakuan atas eksistensi perempuan tidak bisa hanya ditentukan oleh kemahiran mereka dalam hal masak, macak, dan manak sehingga pada akhirnya mengisolasi peran mereka hanya seputar dapur, meja rias dan ranjang. Lebih dari itu, mereka memiliki hak untuk berekspresi secara mandiri.

Gerakan pemberdayaan kaum perempuan muncul dalam kultur peradaban manusia bagaikan cendawan di musim hujan. Namun terlepas dari berhasil atau gagalnya gerakan tersebut, paradoks atau tidaknya teologi feminis itu sendiri, (kita) semua bisa belajar dari kisah "Jaka Tarub dan Tujuh Bidadari". Melalui Jaka Tarub dan Nawang Wulan, laki-laki dan perempuan diajak untuk melihat kembali relasi mereka dalam dunia, membaca secara baru menurut konteks zaman agar mampu menggalang kerja sama yang lebih kooperatif untuk membangun dunia menjadi lebih baik yaitu menuju keselamatan umat manusia. 
